\title{
PENGEMBANGAN MODUL PEMBELAJARAN MENULIS KARANGAN BERBASIS STRATEGI THINK-TALK-WRITE
}

\author{
Agnes Apryliana dan Hany Uswatun Nisa \\ Universitas Muhadi Setiabudi Brebes \\ email: agnesapryliana@gmail.com
}

\begin{abstract}
(Title: The Development of Essay Writing Learning Moduls Based on ThinkTalk-Write Strategy). The curriculum 13 for high school students in class X of the material taught is writing essays. The study aims to determine the development of moduls that can be used in writing essay learning based on think-talk-write (TTW) strategies and the differences in the effectiveness of learning to write essays using the module. The research used the R\&D approach. Based on the results of the analysis of the needs of the students and teachers, it can be concluded the students need special teaching materials in learning to write essays. Therefore, the TTW strategy was chosen as a strategy used to develop teaching materials. The result of the effectiveness test a t score of 28, 273 and 27, 288. This proves the existence of effectiveness in using TTW astrategy-based moduls.
\end{abstract}

Key word: modul, think-talk-write, writing

\section{PENDAHULUAN}

Menulis merupakan kegiatan yang berkaitan dengan kreativitas dalam mengungkap ide, gagasan, dan pendapat. Hasil dari tulisan diharapkan mampu memberikan sumbangsih untuk menyelesaikan berbagai permasalahan yang timbul di masyarakat. Kegiatan menulis menjadi penting untuk mendukung kreativitas dan eksistensi seseorang dalam bidang ilmu yang dimilikinya. Menulis pada hakikatnya adalah menuangkan buah pikiran atau gagasan ke dalam sebuah media tulis melalui kalimat yang dirangkai secara utuh, lengkap, jelas, dan mampu merepresentasikan hal-hal yang dimaksud dalam pikiran, sehingga buah pikiran tersebut mampu dikomunikasikan kepada pembaca dengan jelas (Brown, 2001). Menulis merupakan media komunikasi yang dapat menghubungkan ruang dan waktu. Oleh karena itu, kegiatan menulis menjadi kursial dalam kehidupan manusia. Manusia tidak dapat terlepas dari kegiatan tulis menulis.

Dalam kegiatan pembelajaran di sekolah terutama pada mata pelajaran bahasa Indonesia menulis menjadi salah satu kemampuan yang harus dikuasai oleh peserta didik. Kemampuan menulis siswa akan terlihat dari hasil tulisan mereka yang tidak terlepas dari bimbingan guru. Menulis menjadi satu kom- petensi dasar yang harus diajarkan sejak usia dini. Menulis pada dasarnya merupakan kemampuan tertinggi di antara kemampuan berbahasa lainnya yang harus dikuasai oleh siswa. Senada dengan pendapat Nurgiyantoro (2012) yang menyatakan keterampilan menulis merupakan keterampilan paling akhir dikuasai oleh pelajar bahasa setelah kemampuan mendengarkan, berbicara, dan membaca.

Mertens (2010) berpendapat bahwa menulis adalah kegiatan yang kompleks dan menuntut kognitif. Agar menjadi sukses dalam pembelajaran menulis, siswa memerlukan pemahaman tentang berbagai komponen pendukung mengenai pengetahuan tahapan-tahapan menulis yang dapat digunakan untuk membantu, mengatur,dan mengarahkan siswa dalamproses penulisan. Kegiatan menulis menjadi penting untuk dipelajari dan dikembangkan, terutama dalam bidang keilmuan yang dimiliki oleh seseorang. Pembelajaran menulis di sekolah menjadi penting untuk diajarkan kepada para siswa. Meskipun pembelajaran tulis menulis telah dipelajari kenyataannya kemampuan menulis siswa Indonesia masih belum mampu menyaingi kemampuan menulis siswa dari negara lain, contohnya seperti para siswa dari Malaysia atau negara lain di kawasan Asia Tenggara. 
Kurikulum 2013 (Kemendikbud, 2013) memuat peran penting bahasa sebagai wahana untuk mengekspresikan perasaan dan pemikiran secara estetis dan logis. Pada satu saat, bahasa tidak dituntut dapat mengekspresikan sesuatu dengan efisien karena ingin menyampaikannya dengan indah sehingga mampu menggugah perasaan penerimanya. Pada saat yang lain, penggunaan bahasa hendaknya efisien dalam menyampaikan gagasan secara objektif dan logis supaya dapat dicerna dengan mudah oleh penerimanya. Dua pendekatan mengekspresikan dua dimensi diri, perasaan dan pemikiran, melalui bahasa perlu dilakukan secara berimbang.

Sejalan dengan peran itu, pembelajaran Bahasa Indonesia untuk jenjang Pendidikan Menengah Kelas X menempatkan Bahasa Indonesia sebagai wahana untuk mengekspresikan perasaan dan pemikiran. Didalamnya dijelaskan berbagai cara penyajian perasaan dan pikiran dalam berbagai macam jenis teks. Pemahaman terhadap jenis, kaidah, dan konteks suatu teks ditekankan sehingga memudahkan peserta didik menangkap makna yang terkandung dalam suatu teks. Penyajian perasaan dan pemikiran dalam bentuk teks yang sesuai agar tujuan penyampaiannya tercapai, apakah untuk menggugah perasaan ataukah untuk memberikan pemahaman perlu dilakukan secara terstruktur. Bahasa Indonesia diajarkan bukan sekadar sebagai pengetahuan bahasa, melainkan sebagai teks yang mengemban fungsi untuk menjadi sumber aktualisasi diri penggunanya pada konteks sosial-budaya akademis. Teks merupakan satuan bahasa yang berisi ungkapan makna secara kontekstual.

Terdapat banyak strategi pembelajaran yang telah diciptakan oleh para ahli dibidang pendidikan. Salah satu strategi pembelajaran, yaitu strategi TTW (Think-Talk-Write). ThinkTalk-Write yang selanjutnya dalam penelitian ini akan ditulis dengan TTW. TTW merupakan strategi pembelajaran yang menitikberatkan pada kegiatan berpikir, berbicara (berdiskusi), dan menulis. Strategi ini memungkinkan siswa untuk menggali informasi lebih dalam melalui kegiatan berpikir dan berdiskusi yang selanjutnya menulis.
Strategi TTW memperkenankan peserta didik untuk mempengaruhi dan memanipulasi ide sebelum menuliskannya dan juga membantu siswa dalam mengumpulkan dan mengembangan ide melalui percakapan terstruktur. Strategi ini lebih efektif jika dilakukan dalam bentuk berkelompok. Dalam kelompok ini siswa diminta membaca membuat catatan kecil, menjelaskan mendengar, dan membagi ide Bersama teman kemudian mengungkapkannya melalui tulisan. Strategi Think, Talk, Write adalah strategi yang memfasilitasi peserta didik dalam latihan berbahasa secara lisan dan menukkus Bahasa tersebut dengan lancar. Strateggi TTW didasarkan pada pemahaman terhadap belajar yang merupakan kegiatan social. Strategi TTW mendorong peserta didik untuk berpikir kritis, berbicara, dan kemudian menuliskannya dalam bentuk karang sesuai dengan kaidah dan karakteristik pada masingmasing karangan.

Dalam kegiatan pembelajaran tidak hanya membutuhkan strategi yang tepat, namun juga bahan ajar yang tepat agar dapat digunakan secara bersama-sama oleh guru dan peserta didik. Dalam kegiatan pembelajaran menulis membutuhkan sebuah formulasi tersendiri yang dapat menggabungkan strategi pembelajaran dengan bahan ajar yang digunkaan. Pada umumya di sekolah hanya menggunakan bukubuku yang diterbitkan oleh Badan Penerbitan Nasional Depdiknas. Sebagai buku teks dalam pembelajaran memuat semua materi yang akan diajarkan dalam rentang waktu satu atau dua semester. Hal tersebut menyebabkan adanya ketidak tuntasan atau hanya memberikan penjabaran serta laihan yang singkat. Hal tersebut sangat membatasi pengetahuan peserta didik terhadap materi pelajaran, teruama pada materi menulis karangan.

Terkait hal tersebut, salah satu upaya untuk menumbuhkan minat siswa terhadap pembelajaran menulis karangan dapat dilakukan dengan mengembangan sebuah produk bahan ajar. Bahan ajar yang dikembangkan harus mampu memenuhi kebutuhan siswaa terhadap teori dan praktik menulis karangan. Bahan ajar yang akan dikembangkan ini merupakan bahan ajar yang akan dikemas dalam bentuk buku. Bahan ajar ini dipadukan dengan semua 
kebutuhan peserta didik dan berbagai peristiwa kultural dan tema-tema terbarukan dalam perkembangan dunia. Adapun unsur yang menyusun bahan ajar menulis karangan berbasis strategi TTW disesuaikan dengan anatomi buku pada umumnya, yaitu 1) bagian depan berisi judul bahan ajar (sampul), identtas buku, prakata, profil buku, daftar isi, dan penyajian standar kompetensi dasar dan menulis berbagai jenis karangan, dan dilengkapi oleh RPP yang dapat digunakan guru dalam menerapkan buku ajar dalam pembelajaran. 2) Bagian teks buku berisi hakikat masing-masing karangan (pengertian, karakteristik, kebahasaan, contoh karangan, identifikasi karangan, latihan soal menulis karangan, rangkuman, informasi bahasa. 3) Bagian akhir buku dilengkapi dengan instrument penilaian menulis karangan yang dapat digunakan guru untuk membantu dalam menilai masing-masing jenis karangan, glosarium, dan daftar pustaka.Berdasarkan penjelasan mengenai pentingnya sebuah strategi pembelajaran dan bahan ajar sebagai pendukung oleh karena itu, penelitian ini akan memfokuskan pada penelitian dan pengembangan bahan ajar materi menulis karangan berbasis strategi Think-Talk-Write untuk siswa SMA kelas X di Kabupaten Brebes. Melalui bahan ajar yang dikembangakan, peneliti mengharapkan agar peserta didik makin tertarik dalam pembelajaran menulis karangan dan termotivasi untuk kreatif menulis karangan

Muhaimin (2008) mengungkapkan bahwa bahan ajar adalah segala bentuk bahan yang digunakan untuk membantu guru atau instruktur dalam melaksanakan kegiatan pembelajaran. Bahan ajar adalah segala bentuk bahan, informasi, alat dan teks yang digunakan membantu guru atau instruktur dalam melaksanakan kegiatan belajar mengajar (Majid, 2007). Widodo dan Jasmadi (2008) berpendapat bahwa bahan ajar adalah seperangkat sarana yang berisikan materi pembelajaran, metode, batasan-batasan, dan cara mengevaluasi yang didesain secara sistematis dan menarik dalam rangka mencapai tujuan yang diharapkan, yaitu mencapai kompetensi dengan segala kompleksitasnya. Oleh karena itu, bahan ajar memiliki peran penting bagi guru dan peserta didik untuk mempelajari suatu materi tertentu guna tercapainnya tujuan pembelajaran. Melalui bahan ajar guru menjadi mudah dalam menyampaikan materi dalam proses belajar. Bahan ajar banyak jenis, salah satunya adalah modul yang dilengkapi dengan rencana pembelajaran dan instrumen penilaian.

Menulis pada hakikatnya adalah menuangkan buah pikiran atau gagasan ke dalam sebuah media tulis melalui kalimat-kalimat yang dirangkai secara utuh, lengkap, jelas, dan mampu merepresentasikan hal-hal yang dimaksud oleh pikiran, sehingga buah pikiran tersebut mampu dikomunikasikan kepada pembaca dengan jelas (Brown, 2001). Menulis menjadi media komunikasi yang dapat menghubungkan ruang dan waktu. Kegiatan menulis menjadi kursial dalam kehidupan manusia. Manusia dalam kegiatan sehari-hari tidak dapat terlepas dari kegiatan tulis menulis. Menulis tidak lagi dilihat sebagai cara untuk merekam pikiran, perasaan, dan ide-ide, tetapi juga sebagai sarana utama menghasilkan dan mengeksplorasi pikiran dan ide-ide baru (Kern, 2014).

Menulis adalah kegiatan komunikasi antara penulis dan pembaca, sebuah rencana, hasil dari pemikiran, imajinasi, mengingat, mengkoleksi seluruh data informasi, tulisan menyatukan ruang dan waktu (Moore-Hart, 2010). Abidin (2012) berpendapat bahwa menulis adalah sebuah proses berkomunikasi secara tidak langsung antara penulis dan pembaca. Sebuah tulisan dibuat untuk dipahami maksud dan tujuannya sehingga proses yang dilakukan tidaklah sia-sia. Dalam sudut pandang lain menulis dapat pula dikatakan sebagai kegiatan mereaksi, artinya menulis adalah proses mengemukakan pendapat atas dasar masukan yang diperoleh penulis dari berbagai sumber gagasan yang tersedia.

Keterampilan menulis telah dianggap sebagai keterampilan yang paling sulit untuk diajarkan dan diperoleh karena menulis adalah aktivitas kognitif paling kompleks yang mewajibkan peserta didik untuk memperhatikan konten, struktur kalimat, kosakata, tanda baca, dan ejaan secara bersama-sama (Mourssi, 2013).

Hyland (2004) menjelaskan bahwa menulis merupakan kemampuan yang sangat penting untuk dimiliki oleh setiap orang. Oleh 
karena itu, guru sangat perlu menyampaikan materi atau pengetahuan tentang menulis kepada para siswanya. Menulis bukan hanya sekedar untuk komunikasi tetapi juga sebagai penyelesaian tugas yang bermakna dalam pembelajaran, pemikiran, dan mengorganisir pengetahuan atau gagasan. Dengan kata lain, menulis adalah suatu aktivitas kompleks yang menyertakan beberapa langkah-langkah (Widodo, 2008).

Kegiatan menulis tidak hanya membutuhkan langkah atau tahapan saja, namun juga memerlukan tujuan. Setiap jenis teks memiliki tujuannya masing-masing, sebuah tulisan harus mengandung tujuan yang jelas, dan informasi yang ingin disampaikan penulis harus dikemas dalam bentuk yang efektif. Melalui sejumlah elemen teks yang perlu disusun secara urut dan dituangkan dalam sejumlah kalimat dengan menggunakan tata bahasa yang tepat. Kegiatan tulis menulis menjadi sangat kursial untuk dipelajari.

Strategi TTW memiliki sintak yang sesuai dengan urutannya yaitu berpikir (think), berbicara (talk), dan menulis (write). Berikut ini tahapn yang diperlukan untuk menerapkan srategi TTW dalam pembelajaran menulis (Huda, 2015: 218-220).

\section{Tahap 1: Think (Berpikir)}

Siswa membaca teks berupa soal memungkinkan (kalau memungkinkan dimulai dengan soal yang berhubungan dengan permasalahan sehari-hari atau kontekstual). Pada tahap ini siswa secara individu memikirkan kemungkinan jawaban (strategi penyelesaian), membuat catatan kecil tentang ide-ide yang terdapat pada bacaan, dan hal-hal yang idak dipahami dengan menggunakan bahasanya sendiri.

\section{Tahap 2: Talk (Berbicara/Berdiskusi)}

Siswa diberi kesempatan untuk membicarakan hasil penyelidikannya pada tahap pertama. Pada tahap ini siswa merefleksikan, menyusu, serta menguji (negosiasi sharing) ide-ide dalam kegiatan diskusi kelompok. Kemajuan komunikasi siswa akan terlihat pada dialognya dalam diskusi, baik dalam bertukar ide dengan orang lain ataupun refleksi mereka sendiri yang diungkapkannya kepada orang lain.

\section{Tahap 3: Write (Menulis)}

Pada tahap ini, siswa menuliskan ideide yang diperolehnya dan kegiatan tahap pertama dan kedua. Tulisan ini terdiri atas landasan konsep yang digunakan, keterkaitan dengan materi sebelumnya, strategi penyelesaiannya, dan solusi yang diperoleh.

\section{METODE}

Metode penelitian yang akan digunakan adalah metode pengembangan. Borg and Gall (dalam Sugiyono, 2010: 9) menjelaskan bahwa penelitian dan pengembangan merupakan metode yang digunakan untuk mengembangkan dan memvalidasi produk. Yang dimaksud produk dalam penelitian ini adalah modul untuk pembelajaran menulis karangan berbasis strategi TTW.

Tahap observasi dilakukan sebagai tahap awal dalam penelitian dan pengembangan. Tahap observasi dilakukan dengan tujuan untuk mengetahui proses pembelajaran menulis karangan yang selama ini dilakukan guru di sekolah. Pada tahap observasi peneliti menggunakan angket kebutuhan sebagai teknik pengumpulan data awal.

Penelitian dilakukan di dua SMA Negeri kelas X di Kabupaten Brebes. Kedua SMA Negeri tersebut, yaitu SMA N 1 Bulakamba Brebes dan SMA N 1 Wanasari Brebes. Dari hasil pengambilan sampel pada masing-masing sekolah terpilihlah kelas X1 dan X2 di SMA N 1 Bulakamba Brebes sebagai kelas penelitian. Kelas X3 dan X4 di SMA N 1 Wanasari Brebes sebagai kelas penelitian. Kedua sekolah tersebut belum pernah diteliti atau digunakan sebagai tempat penelitian pengembangan. Waktu penelitian dilakukan pada bulan Mei-Juli tahun pelajaran 2018/2019 dan tahun 2019/2020

Dalam penelitian dan pengembangan bahan ajar untuk pembelajaran menulis karangan adalah guru pengampu mata pelajaran Bahasa Indonesia dan peserta didik kelas X di SMA N 1 Bulakamba Brebes dan siswa kelas X di SMA N 1 Wanasari Brebes. Pemilihan kelas pada masing-masing sekolah dilakukan secara 
random. Serta dosen ahli dibidang pengemabangan bahan ajar menulis karangan.

Dalam penelitian ini terdapat tiga instrumen yang digunakan. Ketiga instrumen tersebut, yaitu (1) instrumen kebutuhan produk berupa bahan ajar untuk pembelajaran menulis karangan, (2) intrumen penilaian draf bahan ajar, dan (3) instrumen penilaian terhadap pembelajaran menulis karangan karangan eksposisi. Instrumen kebutuhan produk akan berupa angket kebutuhan guru dan peserta didik. Instrumen penilaian terhadap draf bahan ajar berupa lembar penilaian yang akan diisi oleh ahli. Instrumen yang digunakan dalam pengujian keefektifan bahan ajar berupa angket penilaian terhadap bahan ajar yang telah dikembangkan dan instrumen penilaian terhadap karangan eksposisi. Lembar penilaian digunakan untuk menilai hasil karangan peserta didik. Kisi-kisi instrumen dalam bentuk angket kebutuhan siswa dan guru, kisi-kisi penilaian bahan ajar, kisi-kisi instrumen uji efktifitas produk, dan instrumen penilaian menulis karangan eksposisi terdapat pada lampiran. Penyusunan instrumen penelitian mengacu pada kisi-kisi.

Teknik analisis data kebutuhan dilakukan dari hasil angket yang diisi oleh guru mata pelajaran Bahasa Indonesia dan peserta didik kelas X di SMA N 1 Bulakamba Brebes dan SMA N 1 Wanasari Brebes yang dipilih secara random. Dari hasil analisis yang dilakukan akan digunakan untuk pembuatan draf bahan ajar berbasis strtegii TTW untuk pembelajaran menulis karangan. Teknik uji validitas produk menggunakan jenis validitas isi yang menggunakan bantuan ahli dibidang bahan ajar untuk memberikan penilaian, evaluasi, dan analisis terhadap draf yang selanjutnya akan digunakan sebagai dasar pijakan untuk membuat bahan ajar menulis karangan berbasis strategi TTW.

\section{HASIL DAN PEMBAHASAN Hasil}

Hasil penelitian yang dipapakan dalam bab ini, yaitu paparan hasil analisis kebutuhan sisa dan guru, paparan hasil penilaian terhadap produk dari ahli, paparan hasil uji coba produk, dan tampilan produk yang berupa modeul pembelajaran menulis karangan untuk siswa SMA kelas X.
Modul yang dihasilkan akan diaplikasikan dalam pembelajaran menulis kkarangan di SMA kelas X baik disemester gasal ataupun semester genap. Modul menulis karangan memuat berbagai macm materi berdasarkan jenis dan karakteristik karangan, serta kebahasaan yang digunakan pada masing-masing materi karangan.

Analisis kebutuhan diterapkan pada siswa dan guru. Dua subjek tersebut dipilih dengan maksud untuk mengetahui berbagai keperluan materi pembelajaran menulis karangan yang dibutuhkan selama pembelajaran di kelas X. Pengambilan data menggunakan sistem angket. Hasil dari angket yang telah terisi oleh siswa dan guru digunakan sebagai bahan acuan dalam pengembangan modul pembelajaran menulis karangan. Selain itu, hasil analisis kondisi buku yang ada menjadi acuan guna menyempurnakan modul pembelajaran. Berikut ini paparan hasil analisis kebutuhan sisa dan guru.

Peserta didik yang digunakan sebagai sumber data adalah siswa SMA kelas X dari dua sekolah. Kedua sekolah yang terpilih adalah SMA N 1 Bulakamba dan SMA N 1 Wanasari. Dari kedua sekolah tersebut akan diwakili oleh peserta didik kelas X dan masing-masing sekolah akan diwakili oleh 2 kelas. SMA N 1 Bulakamba akan diwakili oleh kelas X IPA 1 dan X IPS 1. SMA N 1 Wanasari diwakili oleh kela X IPA 2 dan X IPS 2. Jumlah siswa yang mewakili di SMA N 1 Wanasari adalah 70 siswa, dan di SMA N 1 Bulakamba 70 siswa. Total keseluruhan responden untuk kebutuhan siswa adalah 140.

Analisis kebutuhan peserta didik terhadap modul pembelajaran menulis karangan berbasis strategi TTW terdiri dari enam aspek, yaitu (1) pendapat peserta didik terhadap pembelajaran menulis karangan, (2) sumber belajar yang diguakan dalam pembelajaran menulis karangan, (3) harapan peserta didik terkait buku modul pembelajaran menulis karangan, (4) perluasan materi yang terdapat didalam modul pembelajaran, (5) kebutuhan fisik modul pembelajaran menulis karangan.

Pendapat pesrta didik terhadap materi pembelajaran menulis karangan yang selama ini diperoleh digunakan peneliti untuk me- 
nganalisis kebutuhan materi.Materi menulis karangan untuk siswa SMA kelas X tersebar di semester gasal dan semester genap. Jumlah responden yang memilih point a (sangat penting) sebanyak 130 siswa. Jumlah peserta didik yang memilih poin $b$ (penting) sebanyak 7 siswa, dan peserta didik yang memilih point $\mathrm{c}$ (biasa) sebanyak 3 siswa. Dari hasil tersebut membuktikan bahwa peserta didik menganggap materi tersebut sangat penting dan perlu untuk dipelajari selama 2 semester.

\section{Pembahasan}

Analisis terhadap sumber belajar peserta didik dilakukan dnegna tujuan untuk mengetahui berbagai macam sumber bahan belajar yang selalu guru dan siswa gunakan. Analisis sumber belajar dilakukan sebagai acuan bagi peneliti untuk menggunakan dan mengembangkan sumber belajar yang lebih efektif dan kreatif dalam pembelajaran menulis karangan. Selain itu, analisis terhadap sumber belajar dilakukan guna mengetahui kebutuhan peserta didik terhadap sumber belajar yang dapat digunakan selama pembelajaran menulis karangan.

Analisis sumber belajar menulis karangan terdiri atas tiga aspek, yaitu (1) sumber belajar menulis karangan yang diguakan, (2) pendapat mengenai sumber belajar yang digunakan dalam pembelajaran menusl, dan (3) setuju atau tidak akan adanya bahan ajar khusus dalam pembelajaran menulis karangan.

Pada aspek pertama, yaitu sumber belajar menulis karangan jumlah pemilih 140 siswa. Hal tersebut, menunjukkan bahwa keseluruhan peserta didik memilih buku sekolah elektronik (BSE) yang selalu digunakan dalam pembelajaran menulis karangan. Saat ini peserta didik dan guru menggunakan BSE sebagai buku acuan utama dalam pembelajaran menulis karangan. Aspek kedua, yaitu pendapat terhadap sumber belajar yang digunakan. Berdasarkan hasil pengisian angket yang dilakukan oleh perserta didik terdapat 5 orang yang memilih menarik, 72 oraang memilih membosankan, 27 orang memilih biasa saja, dan 36 memilih tidak memusatkan pada menulis karangan. Dari berbagai macam pendapat, hal tersebut menunjukan bahwa peserta didik mengalami berbagai macam penilaian terhadap sumber belajar yang biasa digunakan. Meskipun ada saja yang berpendapat bahwa sumber belajar yang biasa digunakan oleh peserta didik membosankan dan tidak memusatkan pada pembelajaran menulis karangan. Aspek ketiga, yaitu setuju atau tidak adanya bahan ajar khusus menulis karangan. Dari hasil yang ditunjukkan, bahwa ada 127 siswa yang menjawab ya (setuju), dan 13 siswa memilih tidak (tidak setuju). Hal tersebut menunjukkan bahwa banyak siswa yang menginginkan adanya bahan ajar khusus yang berisikan berbagai macam materi yang berkaitan dengan pembelajaran menulis karangan.

Selanjutnya, analisis yang dilakukan terhadap kebutuhan isi bahan ajar menulis karangan yang terdiri atas delapan aspek, yaitu (1) isi bahan ajar yang digunakan, (2) penjelasan mengenai menulis karangan, (3) judul bahan ajar menulis karangan, (4) penyertaan daftar isi, (5) jenis soal, (6) penyertaan glosarium, (7) penyertaan daftar pustaka, dan (8) penggunaan bahasa.

Terdapat delapan aspek yang menjadi fokus guna mengembangkan bahan ajar menulis karangan yang berbasis strategi TTW. Aspek pertama, yaitu isi bahan ajar yang digunakan. Pada aspek pertama terdapat 131 peserta didik memilih bahan ajar yang berisi hakikat karangan berdasarkan jenisnya, contoh karangan, kebahasaan, diksi, dan latihan soal. Serta 9 siswa memilih bahan ajar yang hanya berisi hakikat dan contoh karangan. Hal tersebut membuktikan bahwa peserta didik menginginkan bahan ajar menulis karangan dengan kelengkapan serta rinci yang terdiri dari jenis-jenis karangan, contoh karangan, kebahasaan, diksi, dan latihan soal. Meskipun ada pula peserta didik yang memilik bahan ajar menulis karangan yang sekedar hakikat dan contohnya saja.

Pada aspek ke dua, yaitu penjelasan mengenai pengertian menulis karangan. Seluruh peserta didik memilih jawaban ya untuk aspek ke dua. Hal tersebut membuktikan bahwa peserta didik membutuhkan penjelasan yang lengkap mengenai hakikat mengarang pada setiap jenis karangan. Pada aspek ke tiga, yaitu judul bahan ajar menulis karangan. Terdapat tiga bentuk judul untuk bahan ajar menulis 
karangan. 'Mahir Menulis Karangan Berbasis Strategi TTW bagi Siswa SMA Kelas X' mendapatkan respon sebesar 27. Judul 'Pandai Menulis Karangan Berbasis Strategi TTW bagi Siswa SMA Kelas X' mendapat respon sebesar 15. Judul 'Kreatif Menulis Karangan Berbasis Strategi TTW bagi Siswa SMA Kelas X' mendapat respon sebesar 98. Dari berbagai macam respon yang diberikan peneliti memutuskan judul 'Kreatif Menulis Karangan Berbasis Strategi TTW bagi Siswa SMA Kelas X' sebagai judul yang akan digunakan untuk bahan ajar menulis karangan.

Pada aspek ke empat, yaitu penyertaan daftar isi. Seluruh peserta didik memberikan respon 'ya' terhadap pentingnya daftar isi dalam sebuah buku ajar menulis karangan. Pada aspek ke lima, yaitu jenis soal. Terdapat tiga pilihan jenis soal, yaitu pilihan ganda yang mendapatkan yang tidak mendapatkan respon dari peserta didik. Soal dalam bentuk uraian mendapatkan respon sebesar 41, dan bentuk soal tugas menulis mendapatkan respon sebesar 99. Hal tersebut, menunjukkan bahwa peserta didik menginginkan soal dalam bentuk tugas menulis karangan pada setiap jenis karangan.

Pada aspek ke enam, yaitu penyertaan glosarium yang mendapatkn respon sebesar 140,membuktikan bahwa peserta didik membutuhkan glosarium dalam buku ajar menulis karangan guna membantu mereka dalam mengingat poin-poin penting. Pada aspek ke tujuh, yaitu penyertaan daftar pustaka mendapatkan jawaban sebesar 140. Adanya daftar pustaka peserta didik mengharapkan untuk kejelasan sumber-sumber yang digunakan dalam bahan ajar menulis karangan. Pada aspek ke delapan, yaitu penggunaan bahasa, siswa menginginkan bahasa yang digunakan lebih mudah dipahami. Hal tersebut dibuktikan dengan respon peserta didik sebanyak 68 .

Analisis selanjutnya dilakukan terhadap bentuk fisik dari bahan ajar pembelajaran menulis karangan yang menjadi harapan peserta didik guna membantu selama belajar. Terdiri atas tiga aspek, yaitu (1) kebutuhan sampul dan ilustrasi sampul, (2) kebutuhan jenis dan ukuran huruf, dan (3) kebutuhan ukuran dan tebal bahan ajar.
Terdapat tiga aspek yang dicemati oleh peneliti. Pada setiap aspek memiliki beberapa pertanyaan yang telah dipilih jawabannya oleh peserta didik sesuai dengan keinginan mereka terhadap bahan ajar menulis karangan. Aspek pertama, yaitu kebutuhan sampul dan ilustrasi sampul yang terbagi kedalam 3 pertanyaan. Ke tiga pertanyaan tersebut adalah 'menurut kalian sampul seperti apakah yang menarik' mendapatkan respon jawaban untuk 'bergambar dan berwarna-warni' sebesar 23, 'bergambar dan hitam putih' sebesar 24, dan jawaban untuk pilihan 'bergambar dan satu warna' sebesar 93. Untuk pertanyaan selanjutnya 'ilustrasi atau gambar seperti apakah yang sesuai untuk sampul bahan ajar menulis karangan' 111 peserta didik kebanyakan menjawab 'foto' sebagai pilihan untuk sampul depan bahan ajar menulis karangan, dan soal 'menurut kalian dimanakah sebaiknya ilustrasi tersebut ditempatkan' sebanyak 24 mahasisa memilih 'di sela-sela/diapit judul', 98 siswa memilih 'di bawah judul, ukuran disesuaikan', dan 18 siswa memilih 'di atas judul, ukuran disesuaikan'. Dari berbagai macam keinginan peserta didik terhadap bahan ajar menulis karangan pada aspek pertama, dapat disimpulkan bahwa bahan jar menulis karangan dibuat dengan sampul yang menarik, menggunakan satu foto yanng diletakan dibawah jadul dengan satu warna yang lembut.

Aspek ke dua, yaitu kebutuhan jenis dan ukuran huruf yang terdiri atas empat pertanyaan. Soal pertama 'berapakah jumlah ilustrasi yang sesuai untuk sampul depan bahan ajar?' 95 siswa memilih 'satu', 14 siswa memilih 'dua', dan 31 siswa memilih 'lebih dari dua'. Soal ke dua 'menurut kalian bagaimanakah sebaiknya ukuran gambar tersebut?' 19 siswa memilih 'besar, 94 peserta didik memilih 'sedang', dan 27 siswa meilih 'kecil'. Pertanyaan ke tiga, yaitu 'warna apakah yang sesuai untuk sampul depan bahan ajar?' berdasarkan pertanyaan tersebut terdapat 32 siswa memilih 'warna-warna mencolok', 91 siswa memilih 'warna-warna lembut', dan 37 siswa memili 'hitam putih'. Pertanyaan ke empat yaitu 'apakah yang sesuai untuk mengisi sampul belakan buku ajar menulis karangan?' terdapat 37 
siswa memilih 'Gambar singkat isi buku', dan 103 siswa memilih 'biografi penulis'.

Aspek ke tiga yaitu kebutuhan ukuran dan tebal bahan ajar yang terbagi ke dalam empat jenis soal. Ke empat jenis soal tersebut, yaitu jenis huruf (font) seperti apakah yang kalian suka untuk judul ahan ajar mendapatkan respon dari peserta didik paling banyak terdapat pada pilihan 'calibri' Sebanyak 106 siswa. Soal 'ukuran huruf yang manakah kalian suka untuk judul bahan ajar' mendapatkan respon sebanyak 87 pada pilihan 'sedang'. Mengenai 'ukuran buku seperti apakah yang sesuai bahan ajar' mendapatkan respon dari peserta didik sebanyak 88 untuk jawaban 'buku kecil'. Soal ke empat, yaitu 'berapa banyak halaman yang sesuai untuk bahan ajar menulis karangan' yang mendapatkan respon paling banyak pada jawaban '40-50', yakni 97 siswa.

Dari ke tiga aspek yang menjadi acuan peneliti untuk menganalisis kebutuhan peserta didik terhadap bentuk fisik bahan ajar menulis karangan berbasis strategi TTW, merangkum sebagai berikut. Buku ajar menulis karangan berbasis strategi TTW akan ditulis dengan sampul yang bergambar dan berwarnawarni lembut, dengan menggunakan satu foto dan ditempatkan dibawah judul yang ukurannya disesuaikan. Huruf yang digunakan dalam bentuk calibri, dengan bentuk buku berukuran sedang dan halaman yang diharapkan sebanyak 40-50.

Analisis kebutuhan guru terhadap bahan ajar menulis karang berbasis strategi TTW terdiri atas lima aspek, meliputi 1) pemahaman guru terhadap bahan ajar, 2) pendapat guru terhadap pembelajaran menullis karangan, 3) kebutuhan isi bahan ajar menulis karangan berbasis strategi TTW, 4) kebutuhan fisik bahan ajar menulis karangan, dan 5) harapan guru terhadap bahan ajar menulis karangan. Ke lima aspek tersebut akan dipaparkan sebagai berikut.

Aspek pertama, yaitu pemahaman guru terhadap bahan ajar. Pemahaman guru terhadap bahan ajar digunakan peneliti guna mengetahui sejauh apa guru mebutuhkan bahan ajar khusus menulis karangan berbasis strategi TTW. Dari hasil angket yang telah diisi oleh guru sejumlah 4 orang memilih jawaban 'ya'. Artinya, bahwa ke empat guru tersebut mengetahui mengenai bahan ajar dan berpendapat bahwa bahan ajar dengan buku teks bersifat sama, yakin membantu guru dan peserta didik selama pembelajaran. Berikut ini tabel analisis kebutuhan guru untuk aspeek yang pertama.

Analisis terhadap aspek ke dua mengenai pendapat guru terhadap pembelajaran menullis karangan. Aspek ini dipilih dengan tujuan untuk mengetahui pengetahuan guru mengenai materi dan sumber-sumber yang biasa guru gunakan selama pembelajaran menulis karangan. Berdasarkan hasil angket yang telah di isi oleh guru hampir semuanya menunjukkan bahwa bahan ajar itu penting dan selama ini belum ada bahan ajar khusus yang membahas mengenai menulis karangan. Para guru berharap dalam pengembangan bahan ajar khusus menulis karangan perlu disertakan standar kompetensi, kompetensi dasar, dan indikator. Berikut ini tabel kebutuhan guru yang berkaitan dengna pengetahun mengenai materi dan sumber belajar.

Aspek ke tiga, yaitu kebutuhan isi bahan ajar menulis karangan berbasis strategi TTW. Berdaarkan hasil pengisian angket, dari ke empat guru berharap bahwa isi materi pada bahan ajar menullis karangan berupa pemaparan materi mengenai hakikat karangan, karakteristik karangan, contoh-contoh karangan, soal menulis karangan, dan kebahasaan. Tema yang mereka pilih adalah tema lingkungan dan sosial-budaya untuk masing-masing jenis karangan yang akan dipelajari selama satu semester. Berikut ini tabel hasil pengisian angket pada aspek ke tiga.

Berdasarkan hasil tabel harapan guru terhadap adanya bahan ajar khusus yang berisikan meteri menulis karangan terdapat 3 guru yang memilih judul "Kreatif Menulis Karangan bagi Siswa SMA Kelas X" sebagai judul bahan ajar menulis karangan. Seluruh guru yang berjumlah 4 orang memilih "buku kecil dengan ukuran A5" sebagai ukuran bahan ajar menulis karangan dengan alasan mudah dibawa dan tidak terasa berat. Adapun tiga orang guru yang memilih 40-50 sebagai jumlah halaman buku ajar menulis karangan, dan ada 1 guru yang memilih 50-60 halaman. Selanjutnya, tiga guru memilih "tugas menulis" sebagai bentuk evaluasi yang cocok digunakan untuk kegiatan pem- 
belajaran menulis dengan menggunakan bahan ajar menulis karangan berbasis strategi TTW.

Produk penelitian ini berupa bahan ajar (modul) dalam pembelajaran menulis karangan yang terdiri dari $4 \mathrm{Bab}$ dengan jenis karangan yang berbeda-beda. Penilaian dilakukan terhadap bahan ajar yang telah jadi. Proses penilaian dilakukan oleh ahli yang telah ditunjuk peneliti. Ahli tersebut, yaitu Dr. Kastam Syamsi, M.Ed dari Program Studi Pendidikan Bahasa dan Sastra Indonesia Universitas Negeri Yogyakarta, dan Dra. Isnaeni Praptamti, M.Pd dari Program Studi Pendidikan Bahasa dan Sastra Indonesia Universitas Muhammadiyah Purwokerto.

Terdapat empat aspek yang dinilai oleh ahli. Ke empat aspek tersebut, yaitu (1) aspek penyajian materi, (2) aspek isi/materi, (3) aspek bahasa dan keterbacaan, dan (4) aspek grafika. Rentang nilai yang diberikan pada tiap poin adalah 1 sampai 4 , dengan nilai terendah 1 dan tertinggi adalah 4 .

Terdapat dua kategori yang dinilai. Kedua kategori tersebut, yaitu kesesuaian teknik penyajian materi yang mendapat nilai rata-rata 73 , dan urutan penyajian materi yang mendapat nilai rata-rata sebesar 74 . Berdasarkan hasil nilai rata-rata yang didapat pada aspek satu menunjukkan bahwa bahan ajar menulis karangan sudah memiliki kesesuaian terhadap teknik penyajian materi dengan urutan yang runtut. Nilai rata-rata keseluruhan tersebut dalam kategori baik. Saran yang diberikan oleh ahli, yaitu untuk lebih memperjelas contoh yang runtut dan berkesinambungan dengan materi yang diajarkan.

Aspek isi materi terdiri dari tujuh poin, yaitu: 1) kesesuaian judul dengan topik bahasan, 2) kelengkapan materi, 3) kesesuaian dalam penerapan strategi TTW, 4) keefektifan contoh-contoh, 5) keefektifan praktik menulis, 6) kesesuaian soal dengan materi, dan 7) kesesuaian soal dengan tingkat pemahaman siswa. Berikut ini hasil penilaian terhadap produk bahan ajar menulis karangan berbasis strategi TTW yang dilakukan oleh dua ahli.

Pada aspek isi materi terdiri dari tujuh kategori yang dinilai oleh para ahli. Hasil dari penilaian tersebut, yakni 1) kesesuaian judul dengan topik bahasan mendapatkan skor rata-rata 73,5. 2) Kelengkapan materi mendapat skor rata-rata sebesar 74,5. 3) Kesesuaian dalam penerapan strategi TTW mendapat skor rata-rata 73. 4) Keefektifan contoh-contoh mendapat skor sebesar 73.5) Keefektifan praktik menulis skor yang didapat, yaitu 75. 6) Kesesuaian soal dengan materi skor rata-rata yang didapatkan sebesar 73,5. 7) Kesesuaian soal dengan tingkat pemahaman siswa mendapat skor rata-rata 74 . Skor rata-rata keseluruhan yang didapat sebesar 73,93. Nilai rata-rata keseluruhan tersebut dalam kategori baik. Masukan yang diberikan oleh ahli untuk melengkapi bahan ajar menulis karangan, yaitu lengkapi kembali materi dengan beragam contoh-contoh karangan dan sesuaikan berdasarkan jenisnya. Saran selanjutnya adalah untuk menambah kembali latihan-latihan menulis karangan dengan bantuan strategi TTW.

Aspek bahasa dan keterbacaan terdiri dari lima poin, yaitu 1) pilihan bahasa dalam judul bahan ajar, 2) pilihan kata yang digunakan, 3) penggunaan ejaan, 4) kesesuaian penggunaan bahasa, dan 5) kesesuaian penjelasan dengan tingkat keterbacaan siswa. terdapat lima kategori yang dinilai oleh ahli berdasarkan aspek bahasa dan keterbacaan. Kategori pilihan bahasa dalam judul bahan ajar mendapatkan skor rata-rata sebesar 72,5. Kategori pilihan kata yang digunakan mendapatkan skor rata-rata 73,5. Kategori penggunaan ejaan skor rata-rata yang dihasilkan, yaitu 74 . Kategori Kesesuaian penggunaan bahasa mendapat skor rata-rata sebas 74 . Kategori kesesuaian penjelasan dengan tingkat keterbacaan siswa skor rata-rata yang didapa, yaitu 74,5. Berdasarkan penjumlahan pada setiap masing-masing kategori dihasilkan skor rata-rata sebesar 73,7. Skor tersebut termasuk dalam kategori baik. Saran yang diberikan ahli adalah untuk memperbaiki pilihan kata yang digunakan dan ejaan.

Aspek grafika terdapat sembilan poin, yaitu 1) kemenarikan judul, 2) kreativitas judul, 3) kesesuaian ukuran, warna, dan tata letak ilustrasi dalam sampul buku ajar, 4) kesesuaian ilustrasi, 5) komposisi warna, 6) pemilihan jenis huruf, 7) ukuran huruf, 8) ukuran bahan ajar, dan 9) tebal bahan ajar. Kategori kemenarikan judul mendapatkan skor rata-rata sebesar 74. kreativitas judul 74. Kategori kese- 
suaian ukuran skor rata-rata yang dihasilkan, yaitu 75. Kategori warna, dan tata letak ilustrasi dalam sampul buku ajar mendapat skor sebesar 75. Kategori kesesuaian ilustrasi mendapat skor sebesar 74,5. Kategori komposisi warna 74,5 . Kategori pemilihan jenis huruf mendapatkan skor sebesar 73,5. Kategori ukuran huruf skor rata-rata yang dihasilkan, yiatu 74 . Kategori ukuran bahan ajar mendapatkan skor sebesar 74. Kategori tebal bahan ajar skor ratarata sebesar 73,5. Berdasarkn jumlah keseluruhan menhasilkan skor rata-rata sebesar 74,22 . Skor rata-rata tersebut dalam kategori baik. Saran yang diberikan oleh ahli, yaitu perbaiki penggunaan warna-warna pada badan buku ajar agar lebih menarik. Bahan ajar menulis karangan berbasis strategi TTW memuat beberapa $\mathrm{Bab}$ yang terbagi berdasarkan pada jenis karangan. Setiap jenisnya memiliki pengembangan materi dan pelatihan soal-soal, serta dilengkapi dengan langkah-langkah yang disesuaikan dengan strategi TTW dalam proses produksi karangan. Pada tahap uji coba produk di lapangan menggunakan kelas $\mathrm{X}$ dengan empat kelas. Dua kelas digunakan sebagai kelas eksperimen dan dua kelas lainnya digunakan sebagai kelas kontrol pada masing-masing sekolah. Pada SMA N 1 Wanasari Brebes menggunakan kelas $\mathrm{X}$ sebagai kelas eksperimen dan kelas X sebagai kelas kontrol. Materi yang diajarkan, yaitu materi menulis eksposisi. Pada SMA N 1 Bulakamba menggunakan kelas X sebagai kelas eksperimen dan kelas X sebagai kelas kontrol, dengan materi menuis karangan eksposisi. Materi karangan eksposisi dipilih berdasarkan pada pembagian materi yang terdapat pada semester 1. Materi menulis karangan eksposisi menjadi salah satu materi yang terdapat pada buku ajar menulis karangan berbasis strategi TTW. Berikut ini hasil uji yang dilakukan terhadp empat kelas yang digunakan.

Berdasar pada hasil skor yang diperoleh dari uji statistik deskripsi yang telah dilakukan di 2 kelas eksperimen membuktikan bahwa adanya peningkatan pada rata-rata hitung yang dihasilkan oleh masing-masing kelas. Kelas eksperimen pada SMA N 1 Wanasari mendapatkan nilai rata-rata Peningkatan pada nilai tersebut membuktikan bahwa me- dia bahan ajar khusus untuk menulis karangan berbasis strategi TTW berhasil digunakan dalam pembelajaran. Untuk memperjelas adanya perbedaan yang signifikan pada penggunaan bahan ajar khusus menulis karangan berbasis strategi TTW dibuktikan dengan uji-t terhadap hasil pasca tes pada 4 kelas yang digunakan. Berikut ini hasil uji-t (uji beda) yang dilakukan pada dua sekolah, yaitu SMA N 1 Wanasari Brebes daan SMA N 1 Bulakamba Brebes. Berdasarkan pada Tabel 1 dan Tabel 2 di atas, hasil uji-t yang dihasilkan menunjukkan bahwa skor t-hitung lebih besar dibandingkan denan ttabel pada masing-masing sekolah. Perbedaan itu menunjukkan bahwa adanya keefektifan dalam penggunaan bahan ajar menulis karangan berbasis strategi TTW yang digunakan pada dua kelas eksperimen.

Bahan ajar dalam bentuk modul pembelajaran menulis karangan berbasis strategi TTW berupa buku uang dikembangkan dengan tujuan untuk meningkatkan kemampuan menulis karangan yang dilakukan oleh peserta didik. Dalam buku ajar ini terdapat empat jenis karangan yang digunakan sebagai materi. Keempat jenis karangan tersebut, yaitu (1) karangan eksposisi, (2) karangan anekdot, (3) karangan negosiasi, dan (4) karangan prosedur. Keempat jenis karangan tersebut terdapat pada semester 1 dan 2 untuk siswa SMA kelas X. Berbagai macam topik akan digunakan pada masing-masing jenis karangan. Diharapkan selama pembelajaran menulis karangan peserta didik berperan aktif dan produktif dengan menghasilkan berbagai jenis karangan yang dibutuhkan. Perencanaan bahan ajar menulis karangan berbasis strategi TTW meliputi konsep dan rancangan.

Berdasarkan pertimbangan kebutuhan peserta didik dan guru sebagai pengguna bahan ajar menulis karangan berbasis strategi TTW judul untuk bahan ajar ini yaitu, "Kreatif Menulis Karangan bagi Siswa SMA Kelas X" denganukuranbukukecil (ukuran A5) dan 40-50 halaman. Pemaparan materi mengenai hakikat karangan, karakteristik karangan, contoh-contoh karangan, soal menulis karangan, dan kebahasaan. Tema-tema yang dipilih, yaitu lingkungan dan sosial-budaya. Bentuk evaluasi yang digunakan adalah tugas menulis karang- 
an pada setiap jenis karangan. Sampul buku menggunakan warna-warna yang lembut dengan satu foto sebagai ilustrasi. Sampul bagian belakang berisikan biodata penulis buku dengan warna-warna yang lembut menyesuaikan dengan warna sampul bagian depan.

Bahan ajar yang dikembangkan oleh peneliti adalah bahan ajar dalam bentuk buku kemampuan menulis karangan. Adapun jenisjenis karangan yang dipelajari, yaitu karangan eksposisi, karangan anekdot, karangan negosiasi, dan karangan prosedur. Adapun strategi yang digunakan selama pembelajaran adalah strategi TTW yang mengedepankan berpikir (Tihink) berbicara (Talk), dan menulis (Write).

Bahan ajar kemapuan menulis karangan ini terbagi menjadi empat bagian. Bab 1 berkaitan dengan jenis karangan eksposisi. Bab 2 berkaitan dengan jenis teks laporan hasil observasi. Bab 3 berkaitan dengan jenis teks negosiasi. Bab 4 berkaitan dengan jenis teks anekdot. Dalam keempat Bab tersebut terdapat hakikat karangan, karakteristik karangan, contoh karangan, kegiatan pembelajaran, penugasan, dan kebahasaan. Tugas akhir yang dilakukan dalam setiap pembelajaran adalah menulis karangan yang tema atau topiknya sudah disiapkan.

Berdasarkan hasil uji coba untuk mengetahui tingkat keefektifan bahan ajar menulis karangan dilakukanlah uji beda yang diterapkan pada siswa SMA kelas X di SMA N 1 Bulakamba dan SMA 1 Wanasari. Hasil uji keefektifan tersebut menunjukkan bahwa bahan ajar terbukti efektif untuk digunakan dalam pembelajaran menulis karangan. Hal tersebut dibuktikan dengan skor-t pada hasil uji beda yang diperoleh pada kelas-kelas yang digunakan sebagai tempat pengambilan data. Pada SMA N 1 Bulakamba skor t yang dihasilkan sebesar 27,882 dan skor t hitung pada SMA N 1 Wanasari menghasilkan skor sebesar 28,273 . Skor t hitung yang dihasilkan lebih besar dibandingkan skor $\mathrm{t}$ tabel dengan signifikasi sebesar 0,05 . Oleh karena itu, bahan ajar ini cukup relevan untuk digunakan sebagai buku pendamping bagi guru dan peserta didik selama pembelajaran menulis karangan atau teks.

\section{KESIMPULAN DAN SARAN}

Berdasarkan hasil pengembangan bahan ajar yang telah dilakukan dan hasil uji keefektifan yang telah diuji cobakan pada empat kelas menunjukkan bahwa bahan ajar menulis karangan ini efektif digunakan sebagai bahan ajar pendamping bagi guru dan peserta didik selama pembelajaran. Dengan adanya bahan ajar ini guru dan peserta didik akan terbantu dari segi penambahan materi dan juga strategi pembelajaran yang dapat sebagai pijakan utama.

\section{UCAPAN TERIMA KASIH}

Ucapat terima kasih kepada Kemenristek Dikti yang telah memberikan pendanaan untuk menunjang terlaksananya kegiatan penelitian ini yang merupakan program Penelitian Dosen Pemula tahun pelaksanaan 2019.

\section{DFTAR PUSTAKA}

Abidin, Y. (2012). Pembelajaran Bahasa Berbasis Pendidikan Karakter. Bandung: Refika Aditama.

Brown, H.D. (2001). Teaching By Principles an Interactive Approach to Language Pedagogy $\left(2^{\text {nd }} e d\right)$. New York: Longman.

Hyland, K. (2004). Second Language Writing. Cambridge: Cambridge University Press.

Huda, M. 2015. Model-Model Pengajaran dan Pembelajaran: Isu-Isu Metodis dan Paradigmatis. Yogyakarta: Pustaka Pelajar.

Kemendikbud. (2013). Kurikulum 2013 untuk Sekolah Menengah Atas. Diambil pada tanggal 14 Maret 2015 dari http://kemendikbud.go.id.

Kern, R.. (2014). Literacy and Language Teaching. New York: Oxford University Press.

Majid, A. 2007. Perencanaan Pembelajaran. Bandung: PT. Remaja Rosdakarya.

Mertens, N. L. (2010). Writing Processes, Tools and Techniques. New York: Nova Science Publishers Inc.

Moore-Hart, M. A. (2010). Teaching writing in diverse classrooms, $k-8$ : Enhancing 
writing through literature, real-life experiences, and technology. Boston: Pearson Education Inc.

Mourssi, A. (2013). Theoretical and practical linguistic shifting from product/guided writing to process writing and recently to the innovated writing process approach in teaching writing for second/ foreign language learners. Journal of Academic Research in Business and Social Sciences, 3, 731-738.

Muhaimin. (2008). Modul Wawasan Pengembangan Bahan Ajar Bab V. Malang: LKP2-1.
Nurgiyantoro, B. (2012). Penilaian PembelajaranBahasaBerbasisKompetensi. Yogyakarta: BPFE Yogyakarta.

Sugiyono. (2010). Metode Penelitian \& Pengembangan: Untuk Bidang Pendidikan, Manajemen, Sosial, Teknik. Bandung: ALFABETA.

Widodo, C. S \& Jasmadi. 2008. Panduan Penyusunan Bahan Ajar Berbasis Kompetensi. Jakarta: Gramedia.

Widodo, H. P. (2008). Designing a genre-based lesson plan for an academic writing course. Diakses pada 21 Februari 2019 di www.enghlisteachingjournal.edu. 